Agrovoc descriptors: azotobacter; allium cepa; nitrogen fertilizers; growth; crop yield; bulbs; dimensions; efficiency; cost analysis

Agris category code: F01, F62, F61

COBISS code 1.01

\title{
Response of onion (Allium cepa L.) to combined application of biological and chemical nitrogenous fertilizers
}

\author{
Tesfaye BALEMI ${ }^{1}$, Netra PAL $^{2}$, Anil Kumar SAXENA ${ }^{3}$
}

Received: January 17, 2007; accepted: June 20, 2007.

Prispelo 17. januarja 2007; sprejeto 20. junija 2007.

\begin{abstract}
A field experiment was conducted during the summer season of 2000-2001 at the Vegetable Research Farm of Indian Agricultural Research Institute (I.A.R.I.), New Delhi (India) to test the efficacy of three Azotobacter strains as a potential supplement to nitrogenous fertilizer in improving growth and yield of onion cv. Pusa Madhvi. The treatments consisted of factorial combination of four levels of nitrogen $\left(0,25,50\right.$ and $\left.75 \mathrm{~kg} \mathrm{~N}^{-1}\right)$ and three Azotobacter strains (CBD-15, AS-4 and M-4) with two uninoculated controls one with full dose of $N(100 \mathrm{~kg}$ $\mathrm{ha}^{-1}$ ) and the other without NPK. Application of $75 \mathrm{~kg} \mathrm{~N} \mathrm{ha}^{-1}$ along with inoculation of CBD-15 was found to have significantly increased most of the growth and yield parameters, soil available nitrogen, and nitrogen content in the bulb followed by M-4 inoculation as compared to application of full dose of nitrogen without the inoculation. Days to bulb initiation were significantly reduced due to inoculation with CBD-15 or M-4 along with $50 \mathrm{~kg} \mathrm{~N}^{-1}$ whereas days to bulb maturity were significantly reduced due to inoculation with any of the strains along with the same $\mathrm{N}$ rate $\left(50 \mathrm{~kg} \mathrm{ha}^{-1}\right)$ as compared to application of full dose of nitrogen without the inoculation. The finding demonstrated a saving of $50 \mathrm{~kg} \mathrm{~N} \mathrm{ha}^{-1}$ without significantly affecting yield and an average increase of $13.5 \%$ marketable yield due to Azotobacter inoculation in the presence of $75 \mathrm{~kg} \mathrm{~N} \mathrm{ha}^{-1}$.
\end{abstract}

Key words: Azotobacter, onion, nitrogenous fertilizer, growth, yield, available nitrogen, bulb diameter

1 Ambo College of Agriculture, P.O. Box 19, Ethiopia

2 Division of Vegetable Crops, IARI, New Delhi110012, India

3 Division of Microbiology, IARI, New Delhi110012, India 


\title{
IZVLEČEK
}

\section{VPLIV KOMBINIRANE APLIKACIJE Azotobacter-JA IN DUŠIČNEGA GNOJILA NA PRIDELEK ČEBULE (Allium cepa L.)}

\begin{abstract}
V letih 2000-2001 je bil na Vegetable Research Farm, Indian Agricultural Research Institute (I.A.R.I.), New Delhi (India) izveden poskus za preverjanje učinkovitost treh sojev Azotobacter kot možnih dodatkov $\mathrm{k}$ uporabi dušičnih gnojil, da bi se izboljšalo rast in pridelek pri čebuli cv. Pusa Madhvi. Poskus je vključeval faktorske kombinacije štirih ravni preskrbljenosti z dušikom $\left(0,25,50\right.$ and $\left.75 \mathrm{~kg} \mathrm{~N}^{-1}\right)$ in tri genotipe Azotobacter (CBD-15, AS-4 and M-4), z dvema neinokuliranima kontrolama, od tega eno $z$ odmerkom $N\left(100 \mathrm{~kg} \mathrm{ha}^{-1}\right)$ in drugo brez gnojenja z NPK. Aplikacija $75 \mathrm{~kg} \mathrm{~N}^{-1}$ je skupaj z inokulacijo CBD-15 dala pomembno povečanje večine parametrov rasti in pridelka, $v$ tleh dostopnega dušika in vsebosti dušika $v$ čebulah po inokulaciji z M-4 , v primerjavi z aplikacijo polnega odmerka dušika a brez inokulacije. Število dni do začetka tvorbe čebul je bilo značilno manjše pri inokulaciji z CBD-15 ali M-4, skupaj z odmerkom $50 \mathrm{~kg} \mathrm{~N}^{-1}$. Število dni do zrelih čebul je bilo značilno manjše pri inokulaciji $\mathrm{s}$ katerim koli genotipom pri enakem odmerku $\mathrm{N}\left(50 \mathrm{~kg} \mathrm{ha}^{-1}\right)$, v primerjavi s polnim odmerkom dušika brez inokulacije. Ugotovitve kažejo prihranek $50 \mathrm{~kg} \mathrm{~N}^{-1}$ brez značilnega znižanja pridelka. Ugotovljeno je povprečno povečanje tržnega pridelka za $13,5 \%$ pri inokulaciji $z$ Azotobacter-jem in odmerku $75 \mathrm{~kg} \mathrm{~N} \mathrm{ha}^{-1}$.
\end{abstract}

Ključne besede: Azotobacter, čebula, dušično gnojilo, rast, pridelek, dostopen dušik, premer čebul

\section{INTRODUCTION}

Onion (Allium cepa) is one of the most important vegetable crops grown and used throughout the world. Onion being among the high nitrogen demanding vegetables, its productivity depends on use of optimum fertilizer rates and if not adequately fertilized, considerable yield losses are apparent. The present day modern agriculture depends heavily on use of chemical fertilizer for boosting crop yield. However, these fertilizers are often in short supply and their indiscriminate use has an adverse effect on long-term soil health and environment, which has received global attention. Moreover, chemical fertilizers are costly and hence are hardly affordable by small and marginal farmers, which constitute the majority of the farming community in developing countries. The most realistic solution is, therefore, to exploit the possibility of supplementing chemical fertilizers with organic ones, more particularly biofertilizers of biological origin. These days biofertilizers have emerged as an important component of integrated nutrient management strategy and had a promise to improve an over all crop performance, yield and nutrient supply. Thus, of late increasing attention is being paid to derive the most benefit from biofertilizers. Biofertilizers are low cost, effective and renewable source of plant nutrients to supplement chemical fertilizers and their role in onion as well as other vegetable production, therefore, assumes a special significance, particularly in the present context of very high cost of chemical fertilizers.

Onion responds well to Azotobacterization and yield increase up to 20 per cent has been reported (Meshram and Shende, 1990). However, there exists wide variation in nitrogen fixing capacity of various strains of Azotobacter (Vinay, 
1998) and strain specificity to crop plants has also been reported (Rajakumar and Lakshman, 1990). The present study was, therefore, conducted with the view to identify efficient strain of Azotobacter and to select a suitable $\mathrm{N}$ level and Azotobacter strain combination(s) for better growth and yield of onion.

\section{MATERIALS AND METHODS}

A field experiment was conducted using onion cultivar Pusa Madhvi during the summer season of 2000-2001 at the Vegetable Research Farm of Indian Agricultural Research Institute (IARI), New Delhi, on sandy loam soil having a pH of 7.9. Four levels of nitrogen (0, 25, 50 and $75 \mathrm{~kg} \mathrm{~N}^{-1}{ }^{-1}$ ) and three Azotobacter strains (CBD-15, AS-4 and M-4) were combined factorially with two additional uninoculated controls one with full dose of $\mathrm{N}, 100 \mathrm{~kg}$ $\mathrm{N} \mathrm{ha}{ }^{-1}$, (standard practice) and the other without NPK (absolute control). A total of 14 treatments including controls were laid out in Randomized Block Design (RBD) with three replications. A plot size of $4.68 \mathrm{~m}^{2}$ and spacing of $10 \mathrm{~cm} \times 15 \mathrm{~cm}$ were used. A carrier based (Charcoal: Soil, 3:1) inoculum of each of the Azotobacter strain @ $500 \mathrm{~g} \mathrm{ha}^{-1}$ was suspended in water to prepare a slurry and seedlings were uprooted from the nursery beds and dipped in the respective Azotobacter strain slurry for transplanting in the main field. Only half dose of nitrogen as urea was applied at the time of transplanting and the rest half was applied in two equal splits at 30 and 50 days after transplanting. Full doses of phosphorus as single super phosphate and potassium as muriate of potash were applied to all the treatments at transplanting @ $50 \mathrm{~kg} \mathrm{P}_{2} \mathrm{O}_{5}$ and $75 \mathrm{~kg} \mathrm{~K}_{2} \mathrm{O}$ ha $^{-1}$, respectively. Data was recorded on growth parameters such as plant height, number of leaves per plant both at 45 and 90 days after planting. Observation was also made on days to bulb initiation, days to maturity, bulb weight, bulb diameter, total and marketable yields, bulb nitrogen content and soil available nitrogen.

\section{RESULTS AND DISCUSSION}

\section{Plant height and number of leaves per plant}

At 45 days after transplanting (DAT), only plant height was significantly influenced due to Azotobacter inoculation under all levels of nitrogen tested when compared to the control with $100 \mathrm{~kg} \mathrm{~N}^{-1}$ (Table 1). However, at 90 DAT, both plant height and number of leaves per plant was significantly influenced due to nitrogen amendment with Azotobacter inoculation. Application of $75 \mathrm{~kg} \mathrm{~N}$ ha-1 in combination with CBD-15 or M-4 significantly improved all parameters over the control treatment with $100 \mathrm{~kg} \mathrm{~N} \mathrm{ha-1.} \mathrm{Such}$ increase in plant height due to Azotobacter inoculation have also been reported by (Badaway and Amer, 1974; Martinez et al., 1994) in tomato and (Dibut et al., 1993; Rita, 1993 and Mandhare et al., 1998) in onion.

\section{Days to bulb initiation and maturity}

Days to bulb initiation and maturity showed variations both among the nitrogen levels and Azotobacter strains. In the absence of nitrogen, inoculation of Azotobacter did not significantly reduce the duration of bulb initiation and maturity. Similarly, inoculation of Azotobacter strain in the presence of 25 and $75 \mathrm{~kg} \mathrm{~N}$ ha-1 resulted in days to bulb initiation and maturity that was statistically at par with both uninoculated controls. However, application of 50 $\mathrm{kg} \mathrm{N}$ ha-1 along with the inoculation of CBD-15 or M-4 resulted in 4 and 3.7 
days earlier bulb initiation, respectively over the standard control. Likewise, application of the same $\mathrm{N}$ level (50kg N ha-1) along with the inoculation of any of the Azotobacter strains led to 1.7 to 2.7 days earlier bulb maturity as compared to the full dose of nitrogen (100 kg N ha-1) application without the inoculation. Similarly, early bulb initiation and maturity in onion was reported by Rita (1998) due to Azotobacter inoculation. The earliness in bulb initiation and maturity may be attributed to the ability of the bacterium to produce growth promoting substances which might have induced bulbing at earlier stage and there by enhanced chance of early crop maturity. Further more, inoculation along with high dose of nitrogen could not be as effective as inoculation along with moderate or lower doses in reducing days to maturity due to prolonged vegetative growth period in the former case.

\section{Bulb diameter and 10 bulb weight}

An overall increase of $11.2 \%$ and $8.5 \%$ higher horizontal and vertical bulb diameter, respectively over the control treatment with $100 \mathrm{~kg} \mathrm{~N}^{-1}$ were obtained due to inoculation of CBD-15 along with $75 \mathrm{~kg} \mathrm{~N} \mathrm{ha}^{-1}$ and it was closely followed by the treatment with $75 \mathrm{~kg} \mathrm{~N} \mathrm{ha}^{-1}+\mathrm{M}-4$ (Table 1). The values for both treatments were statistically significant when compared to the control treatment with $100 \mathrm{~kg} \mathrm{~N} \mathrm{ha}^{-1}$. Similar trend was observed for weight of 10 bulbs. Amendment of $75 \mathrm{~kg} \mathrm{~N} \mathrm{ha}^{-1}$ through inoculation of either CBD-15 or M-4 resulted in 15 and $12.5 \%$ increased weight of 10 bulbs, respectively over the control treatment with $100 \mathrm{~kg} \mathrm{~N} \mathrm{ha}^{-1}$ (Table 1).

\section{Total and marketable yields}

Supplementation of nitrogen fertilizer with Azotobacter inoculation markedly increased both total and marketable yields. Supplementing $75 \mathrm{~kg} \mathrm{~N}^{-1}$ through inoculation of either CBD-15 or M-4 gave an increase of 12.9 and $9.9 \%$ in total yield; and 15 and $11.9 \%$, respectively in marketable yields over the uninoculated control with $100 \mathrm{~kg} \mathrm{~N} \mathrm{ha}^{-1}$. The result also clearly demonstrate that inoculation of CBD-15 or M-4 in the presence of $50 \mathrm{~kg} \mathrm{~N}$ ha-1 gave yield statistically at par with the uninoculated control having full dose of $\mathrm{N}(100 \mathrm{~kg}$ $\mathrm{N} \mathrm{ha}^{-1}$ ) there by resulting in a net saving of $50 \mathrm{~kg} \mathrm{~N}^{-1}$. Similarly, (Konde et al., 1978 and Rita, 1998) have also reported increased total yield in onion due to Azotobacter inoculation. Bhonde et al. (1997) reported the highest marketable yield (230.62 q ha-1) in onion due to combined application of Azotobacter and $50 \%$ recommended dose of nitrogenous fertilizer.

\section{Soil available nitrogen and bulb nitrogen content}

A remarkable increase in soil available nitrogen after crop harvest was observed due to supplementation of $75 \mathrm{~kg} \mathrm{~N} \mathrm{ha}^{-1}$ with inoculation of CBD-15 over the control with full dose of nitrogen as well as over the absolute control by giving $23.6 \mathrm{~kg}$ ha ${ }^{-1}$ and $104.5 \mathrm{~kg} \mathrm{ha}^{-1}$ higher soil available nitrogen over both the controls, respectively (Table 2). Inoculation with all the strains except in the 
absence of applied nitrogen, have furnished the soil with additional quantity of available nitrogen compared to the amount that was present before the crop was planted (236.37 $\mathrm{kg}$ ha-1). Likewise these findings draw support from several other earlier reports. Ahmad (1998) reported the highest soil available nitrogen due to application of $145 \mathrm{~g} \mathrm{~N}$ tree $-1+$ Azotobacter strain CBD-15 over $145 \mathrm{~g} \mathrm{~N}$ tree $^{-1}+$ Azotobacter strain M-4 and all other treatments which is in close conformity with the present finding. Nitrogen content in bulbs was significantly increased due to supplementation of $75 \mathrm{~kg} \mathrm{~N}^{-1}$ with either CBD-15 or M-4 over the control with full dose of nitrogen (Table 2). These two treatments gave 0.24 and 0.16 per cent higher nitrogen in bulbs over the standard practice and 1.17 and 1.0 per cent higher nitrogen in bulbs over the absolute control, respectively. A significant increase in percent nitrogen in grain as well as stover of maize was also reported due to Azotobacter inoculation along with moderate amount of nitrogenous fertilizer by Meshram and Shende (1982). The increase in nitrogen content in bulbs might be due to better root development that was achieved as a result of inoculation with efficient strains, which led to enhanced nutrient uptake.

\section{CONCLUSION}

Of the three strains of Azotobacter used, two strains (CBD-15 and M-4) in the presence of $75 \mathrm{~kg} \mathrm{~N}^{-1}$ were found to have significantly improved the growth and yield parameters, nitrogen content in the bulb and soil available nitrogen when compared to uninoculated control with $100 \mathrm{~kg} \mathrm{~N}^{\mathrm{N}} \mathrm{N}^{-1}$. An average increase of $13.5 \%$ in marketable yield was achieved due to effective Azotobacter strain inoculation in the presence of $75 \mathrm{~kg} \mathrm{~N} \mathrm{ha}^{-1}$ over uninoculated control with $100 \mathrm{~kg} \mathrm{~N}^{-1}$. Inoculation with the effective strains (CBD-15 and M4) also enabled a saving of $50 \mathrm{~kg} \mathrm{~N}^{-1}$ with out affecting total and marketable yields as compared to the uninoculated control treatment with $100 \mathrm{~kg} \mathrm{~N}$ ha-1. The increase in growth and yield parameters in the inoculated treatments can be attributed to the multiple effects of Azotobacter such as their ability to fix atmospheric nitrogen (Pandey et al., 1989) suppression of pathogenic microorganisms (Lakshmi Kumari et al., 1972; Meshram and Jagar, 1983), production of growth promoting substances (Brown, 1974, Shende et al., 1975). Moreover, its role in solublization of phosphate (Iswaran and Marwaha, 1981) and general improvement in nutrient uptake of the plant due to root proliferation might have also considerably contributed to enhanced growth and yields of the inoculated treatments in these findings. 


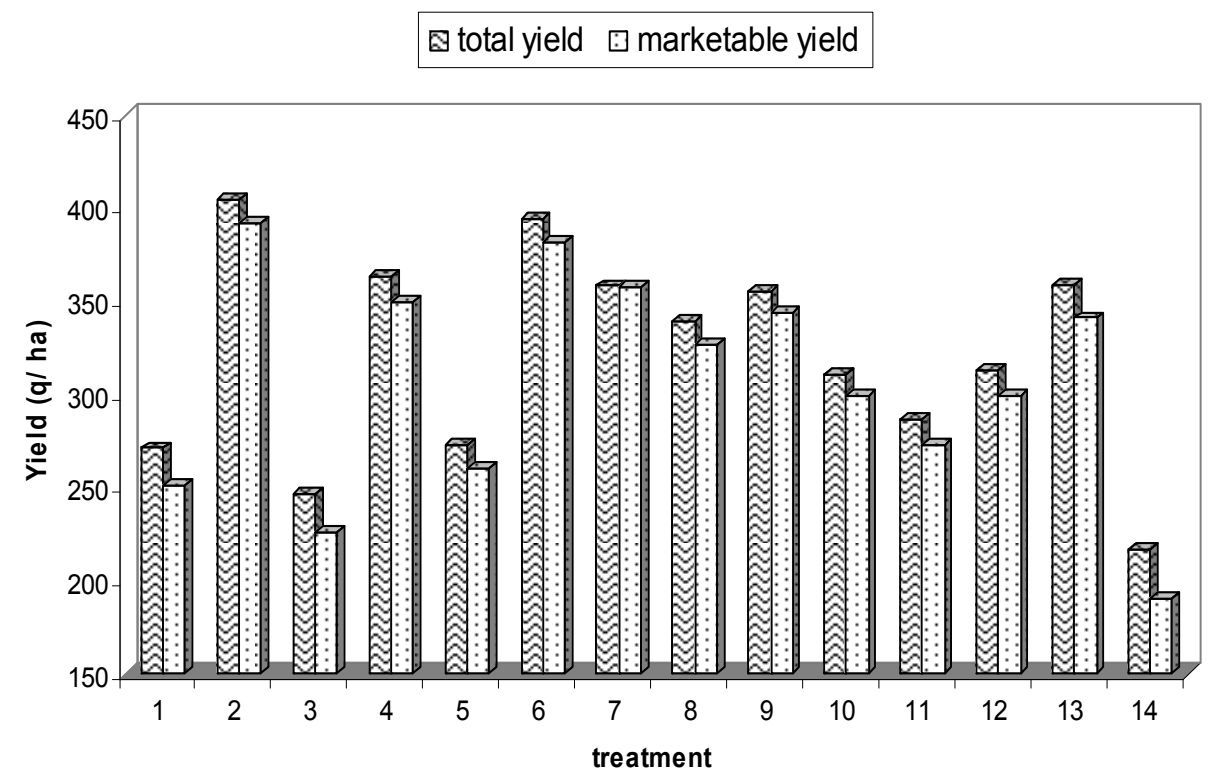

Figure 1. Total and marketable yields of onion as affected by combined application of Azotobacter strains and reduced $\mathrm{N}$ doses

Table 1. Various growth parameters of onion as affected by combined application of Azotobacter strains and reduced $\mathrm{N}$ doses

\begin{tabular}{|c|c|c|c|c|c|c|c|c|c|c|}
\hline \multirow[t]{2}{*}{ Treat. } & \multicolumn{2}{|c|}{ Plant height $(\mathrm{cm})$} & \multicolumn{2}{|c|}{$\begin{array}{l}\text { No. of leaves } \\
\text { per plant }\end{array}$} & \multirow{2}{*}{$\begin{array}{l}\text { Days to } \\
\text { bulb } \\
\text { initiation }\end{array}$} & \multirow[t]{2}{*}{$\begin{array}{l}\text { Days to } \\
\text { maturity }\end{array}$} & \multicolumn{2}{|c|}{ Bulb diameter $(\mathrm{cm})$} & \multicolumn{2}{|c|}{$\begin{array}{c}10 \text { bulb weight } \\
\text { (g) }\end{array}$} \\
\hline & $\begin{array}{c}45 \\
\text { DAT }\end{array}$ & $\begin{array}{c}90 \\
\text { DAT }\end{array}$ & $\begin{array}{c}45 \\
\text { DAT }\end{array}$ & $\begin{array}{c}90 \\
\text { DAT }\end{array}$ & & & Vertical & Horizontal & Fresh & Dry \\
\hline $\mathrm{T} 1$ & 30.27 & 47.87 & 4.20 & 7.03 & 73.33 & 128.7 & 4.10 & 5.33 & 656.7 & 56.40 \\
\hline $\mathrm{T} 2$ & 39.63 & 59.63 & 4.87 & 8.67 & 70.33 & 127.0 & 5.67 & 6.80 & 920.0 & 97.40 \\
\hline T3 & 29.80 & 47.00 & 4.07 & 6.80 & 73.67 & 129.0 & 4.00 & 5.17 & 640.0 & 53.30 \\
\hline $\mathrm{T} 4$ & 36.00 & 54.43 & 4.80 & 8.13 & 71.00 & 127.3 & 5.23 & 6.17 & 880.0 & 89.00 \\
\hline T5 & 30.93 & 49.00 & 4.32 & 7.17 & 73.00 & 128.3 & 4.23 & 5.33 & 673.3 & 59.23 \\
\hline T6 & 39.40 & 58.87 & 4.87 & 8.53 & 70.67 & 127.0 & 5.60 & 6.73 & 900.0 & 96.83 \\
\hline $\mathrm{T} 7$ & 35.90 & 55.23 & 4.67 & 7.99 & 68.00 & 125.0 & 5.00 & 6.23 & 876.7 & 86.33 \\
\hline $\mathrm{T} 8$ & 34.53 & 53.67 & 4.55 & 7.50 & 69.33 & 126.0 & 4.87 & 6.03 & 836.7 & 81.37 \\
\hline T9 & 34.77 & 54.33 & 4.60 & 7.97 & 68.33 & 125.3 & 5.03 & 6.10 & 860.0 & 83.20 \\
\hline T10 & 32.60 & 51.03 & 4.50 & 7.60 & 71.67 & 126.3 & $4 . .60$ & 5.63 & 750.0 & 69.63 \\
\hline T11 & 31.53 & 50.17 & 4.40 & 7.33 & 72.33 & 126.7 & $4 . .47$ & 5.50 & 740.0 & 67.63 \\
\hline T12 & 33.30 & 52.13 & 4.53 & 7.60 & 71.33 & 126.0 & $4 . .70$ & 5.73 & 770.0 & 73.30 \\
\hline T13 & 36.07 & 54.00 & 4.73 & 8.00 & 72.00 & 127.7 & 5.10 & 6.27 & 880.0 & 83.13 \\
\hline $\mathrm{T} 14$ & 27.67 & 44.17 & 3.39 & 6.13 & 74.00 & 130.0 & 3.73 & 4.37 & 560.0 & 49.07 \\
\hline $\begin{array}{l}\text { C.D. } \\
(5 \%)\end{array}$ & 3.20 & 4.10 & 0.39 & 0.51 & 3.35 & 1.52 & 0.42 & 0.45 & 37.40 & 13.57 \\
\hline \multicolumn{4}{|c|}{$\begin{array}{l}\mathrm{T}_{10}=25 \mathrm{~kg} \mathrm{~N} \mathrm{ha}^{-1}+\mathrm{CBD}-15 \\
\mathrm{~T}_{13}=\text { Full dose of } \mathrm{N}(100 \mathrm{~kg} \mathrm{~N} \\
\left.\text { ha }^{-1}\right) \text { without Azotobacter } \\
\text { (standard practice) }\end{array}$} & \multicolumn{3}{|c|}{$\begin{array}{l}\mathrm{T}_{11}=25 \mathrm{~kg} \mathrm{~N} \mathrm{ha}^{-1}+\mathrm{AS}-4 \\
\mathrm{~T}_{14}=\text { Without NPK and } \\
\text { Azotobacter (absolute } \\
\text { control) }\end{array}$} & \multicolumn{4}{|c|}{$\mathrm{T}_{12}=25 \mathrm{~kg} \mathrm{~N} \mathrm{ha}^{-1}+\mathrm{M}-4$} \\
\hline
\end{tabular}


BALEMI, T. in sod.: Response of onion (Allium cepa L.) to combined application...

Table 2: Soil available nitrogen and bulb nitrogen content as affected by combined application of Azotobacter strains and reduced nitrogen doses

\begin{tabular}{lll}
\hline Treatment & $\begin{array}{l}\text { Available nitrogen in } \\
\text { soil (kg ha } \mathbf{~}^{-1} \text { ) }\end{array}$ & $\begin{array}{l}\text { Nitrogen content (\%) } \\
\text { in Bulbs }\end{array}$ \\
\hline & & \\
$\mathrm{T}_{1}$ & 220.5 & 2.53 \\
$\mathrm{~T}_{2}$ & 295.5 & 3.57 \\
$\mathrm{~T}_{3}$ & 214.5 & 2.50 \\
$\mathrm{~T}_{4}$ & 262.9 & 3.35 \\
$\mathrm{~T}_{5}$ & 224.2 & 2.60 \\
$\mathrm{~T}_{6}$ & 290.6 & 3.49 \\
$\mathrm{~T}_{7}$ & 269.7 & 3.22 \\
$\mathrm{~T}_{8}$ & 254.5 & 3.16 \\
$\mathrm{~T}_{9}$ & 267.6 & 3.21 \\
$\mathrm{~T}_{10}$ & 245.3 & 2.89 \\
$\mathrm{~T}_{11}$ & 241.0 & 2.79 \\
$\mathrm{~T}_{12}$ & 249.5 & 2.91 \\
$\mathrm{~T}_{13}$ & 271.9 & 3.33 \\
$\mathrm{~T}_{14}$ & 191.0 & 2.40 \\
\hline C.D. (at 5\%) & 23.40 & 0.12 \\
\hline
\end{tabular}

\section{LITERATURE}

Ahmad, F.MD. 1998. Response of Azotobacter chroococcum in Integrated Nutrient Management in mango cv. Amarpali. Ph.D (Hort.). Thesis submitted to Faculty of P.G.S., I.A.R.I, New Delhi.

Badaway, F.H. and Amer, S.B. 1974. The effect of inoculation with Azotobacter on the growth of wheat and tomato plants. Libyan Journal of Agriculture. 3: 141-43.

Bhonde, S.R. Sharma S.B. and Chougule A.B. 1997. Effect of biofertilizer in combination with nitrogen through organic and inorganic sources on yield and quality of onion. National Hort. Res. and Development Foundation, Nasik, Maharashtra 17(2): 1-3.

Brown, M.E. 1974. Seed and root bacterization. Ann. Rev. Phytopath. 12: 181-197.

Dibut, B., Martinez, R., Gonzalez, R. and Villegas, D.R. (eds.). (1993). Stimulation of growth and yield of onions by bacterization in red ferrallitic soils. Memorias del XI congreso latioamericano de la cienica del suelo Y II congreso cubano de la cienica del suelo Vol.1: quimica, fisica Y biololgia de suelos. 223-225.

EL-Shanshoury, A.R. Hassan, M.A. and Abdel-Ghaffar, B.A. 1989. Synergistic effect of vascular-arbuscular-mycorrhizas and Azotobacter chroococcum on growth and nutrient contents of tomato plants. Phyton-Horn. 29(2): 203-212. 
Iswaran, V. and Marwaha, T.S. 1981. Nitrogen fixation by Azotobacter chroococcum in the presence of different phosphatic compound and its solublization. Zbl. Bakt. Parasit. Infect. Hyg. 123: 198.

Lakshmi Kumari, M., Vijayalakshmi, K. and Subba Rao, N.S. 1972. Interaction between Azotobacter species and fungi. In vitro studies with Fusarium moniliforme sheld. Phytopathol. Z. 75(1): 27-30

Mandhare, V.K., Patil, P.L. and Gadekar, D.A. 1998. Phosphorus uptake of onion as influenced by Glomus fesciculatum, Azotobacter and phosphorus levels. Agricultural Science Digest Karnal. 18 (4): 228-230.

Martinez, Vienra R., Dibut, Alvarez B., Gonzalez, Perez P. and Acosta, Rivera M.C. 1994. Effect of the application of biopreparation based on Azotobacter chroococcum on tomato and onion in red ferratic soils. 90 anos-de la Estacion Experimental Agronomica de santiago de las vega. 167-184.

Meshram, S.U. and Jagar, G. 1983. Antagonism of Azotobacter chroococcum isolates to Rhizoctonia solani. Neth. J. Plant Pathol. 89:191.

Meshram, S.U. and Shende, S.T. 1982. Total nitrogen uptake by maize with Azotobacter inoculation. Plant and Soil, 69(2): 275-279.

Meshram, S.U. and Shende, S.T.. 1990. Response of onion to Azotobacter chroococcum inoculation. J. Maharashtra Agric. Univ. 15(3): 365-336.

Pandey, A. Shende, S.T. and Apte, R.G. 1989. Effect of Azotobacter chroococcum seed inoculation on its establishment in rhizosphere, on growth and yield and yield attributing parameters of cotton. Zentralbl. Mikrobiol. 144: 595-604.

Rajakumar, K. and Lakshman, M. 1990. Strain specificity of Azotobacter chroococcum to crop plants. Indian J. of Microbiol. 30(2): 221-224.

Rita, N. Ukey 1998. A pragmatic approach for supplementation of Chemical Fertilizers with Biofertilizers to onion crops (Allium cepa L.). Ph.D (Agric.). Thesis submitted to Faculty of P.G.S., I.A.R.I., New Delhi.

Shende, S.T., Apte, R.G. and Singh, T. 1975. Multiple action of Azotobacter. Indian J. plant breeding.35: 314.Verma. O.P. and Shende, S.T. 1993. Azotobacter a biofertilizer for vegetable crops. Biofertilizer Newsletter 1(2): 6-10.

Vinay, G., Gupta, R.D. and Bharadwaj, K.K.R. 1998. Abundance of Azotobacter in great soil groups of North West Himalayas. Journal of Indian Society of Soil Science. 46(3): 379-383. 